\title{
An Analysis of the Causes of Regional Migration Using Garrett's Scale
}

\author{
Dr .Uma,H.R. Madhu.G.R. Mahammad Habeeb \\ Dos in Economics And Co Operation University of Mysore
}

\begin{abstract}
For many poor people around the world migration is a way of life, and has been for centuries. But globalization has radically altered the scale of migration: people are now more aware of opportunities elsewhere and it has become easier for them to travel.

The seasonal migration of agricultural labourers is not a new phenomenon in Karnataka and India. Britishers had mobilized labour force for commercial crop production, mining and for other administrative purposes during their rule. As a result of the defective policies of agricultural development the regional disparity is increasing even after independence leading to the increase in the seasonal migration of agricultural labourers. In the state of Karnataka there is a wide gap between South and North Karnataka as far as development is concerned and this regional disparity has become a political issue. Many social, economic, political and psychological reasons pull them to migrate for survival and improvement of livelihood.

This paper is an effort to identify some of the main causes for the agricultural labour migration from north Karnataka to south Karnataka

Key words: North Karnataka, South Karnataka, agriculture labour, regional migration.
\end{abstract}

\section{Introduction}

The term migration was usually understood to cover all cases where the decision to migrate was taken freely by the individual concerned for reasons of "personal convenience" and without intervention of an external compelling factor; it therefore applied to persons, and family members, moving to another country or region to improve their material or social conditions and improve the prospect for themselves or their family. The United Nations defines migrant as 'an individual who has resided in a foreign country for more than one year irrespective of the causes, voluntary or involuntary, and the means, regular or irregular, used to migrate.' Under such a definition, those travelling for shorter periods as tourists and business persons would not be considered as migrants. However, common usage includes certain kinds of shorter-term migrants, such as seasonal farmworkers who travel for short periods to work in planting or harvesting farm products."

Migration refers to the movement of people from one geographical location to another, either on a temporary or permanent basis (Ekong 2003). It is a common observation all over the world that rural-urban migration is the dominant pattern of internal migration. Migration is a selective process affecting individuals or families with certain economic, social, educational and demographic characteristics. People migrate in response to prevailing conditions and the reasons for it differ from one individual to another

Agricultural labourers, especially in smaller villages away from towns and cities, are generally unskilled workers carrying on agricultural operation for the centuries old traditional wages. Most agricultural workers belong to the depressed classes, which have been neglected for ages. The low caste and depressed classes have been socially handicapped and they never had the courage to assert themselves. In some parts of India, agricultural labourers are migratory, moving in search of jobs at the time of harvesting, this type of migration influenced by many reasons.

\section{Review of literature:}

Guido Dorigo, Waldo Tobler, (2010)reveal that the mathematics of a push-pull model are shown to incorporate many of Ravenstein's laws of migration, to be equivalent to a quadratic transportation problem, and to be related to the mathematics of classical continuous flow models. These results yield an improved class of linear spatial interaction models. Empirical results are presented for one country.

Douglas S. Massey and Felipe Garcia Espansa,(2010) asserts that the social process of network growth helps to explain the rapid increase in the migration of Mexicans to the United States during the 1970s. Migrant networks are webs of social ties that link potential migrants in sending communities to people in receiving societies, and their existence lowers the costs of international movement. With each person who becomes a migrant, the cost of migration is reduced for a set of friends and relatives, inducing them to migrate and further 
expanding the network. As a result of this dynamic interaction, network connections to the United States have become widespread throughout Mexico, and the probability of international migration from that country is high. Manon Domingues, Dos Santo Thiser,(2000) analyses the dynamics of migratory flows and growth in a developing economy. They show that when workers freely choose their location, some natives can rationally decide to return to their home country after they have accumulated a certain amount of knowledge abroad, while some prefer to stay permanently in the same economy (either at home or abroad). They point out that worker mobility can have an expansionary effect on the developing economy. Moreover, we show that in the long-run, as the sending economy develops, fewer natives are likely to emigrate and more migrants are likely to return.

Shigemi Yabuuchia, Sarbajit Chaudhurib(2005) develops a three sector general equilibrium structure with diverse trade pattern and imperfection in the unskilled labour market to analyze the consequences of international mobility of skilled and unskilled labour on the skilled-unskilled wage inequality in the developing economies. The analysis finds that an emigration (immigration) of either type of labour is likely to produce a favorable effect on the wage inequality. In particular, the result of emigration (immigration) of skilled labour on the relative wage inequality is counterintuitive. These results have important policy implications for an overpopulated developing country like India

Manolo I. Abella (2005) while the growth of trade may have substituted for potential movements of labour, its overall impact has been to stimulate economic growth and employment, and social and demographic changes which in turn create shortages of labour. As the regional economy continues to expand at a rapid pace, pressures will increase for importing foreign labour to do jobs that national workers no longer want.

The World Bank's 2006 Global Economic Prospects Report asserts that "migration should not be viewed as a substitute for economic development in the country of origin [as ultimately] development depends on sound domestic economic policies."

Naresh Kumar and A.S. Sidhu (2005) attempt to identify the push and pull factors which influence workers' inter-state migration, on the basis of perceptions of workers. A sample of 200 workers drawn from 25 brick-kilns located in three districts of Punjab was interviewed. This study found that industrial development, better job opportunities and comparatively higher wages in Punjab have emerged as the most important pull factors which motivate labour to migrate. But lack of development, inadequate agricultural land and poor economic conditions of family forced laborers to migrate out of its native place. The study further found that economic factors have emerged more significant as compared to non-economic factors in the process of migration. Study recommends that in view of the slow absorption rate in the urban industrial sector, the labour migration should be regulated. Concrete plans and their effective implementation are necessary in order to reach the people.

\section{Research gap:}

Migration is one of the common trends in these days. In the same way agriculture labour migration is also common in these days. Agriculture labourer face so many problems in his living condition and these problems push him from his native place and migrate to other places where he get good employment and income opportunity. In Karnataka there is lot of disparities between North and South Karnataka and the drought is more prevalent in North which has led to the migration of agricultural labourers from north to south Karnataka in search of jobs. This study focuses on this type of migrant labourers who have migrated from north Karnataka to south Karnataka for employment in construction fields, and tries to identify which factor is acting more significantly in this type of regional migration with the help of Garrett's scale.

\section{Objective the paper:}

To identify the important push and pull factors for the migration of agricultural labours.

\section{Hypothesis}

Ho: unemployment is not the major cause for the migration of agricultural labours

H1: unemployment is the major cause for the migration of agricultural labours

\section{Methodology:}

Details regarding the socio-economic conditions of the selected laborers are based on the information collected through interview schedule. 100 respondents are selected from different construction fields in Mysore. Primary data collected from the respondents with the help of questionnaire. Garrett's ranking technique is used for ranking the pull factors to know which of them are more influential and which is less influential in this internal regional migration. 


\section{Garrett's Ranking Technique}

To find out the most significant factor which influences the respondent, Garrett's ranking technique was used. As per this method, respondents have been asked to assign the rank for all factors and the outcome of such ranking has been converted into score value with the help of the following formula:

\begin{tabular}{cc} 
Percent Position $\quad=\quad 100\left(\mathbf{R}_{\mathrm{ij}}-0.5\right)$ \\
\hdashline$-\cdot-\cdot-$ \\
$\mathrm{N}_{\mathrm{j}}$
\end{tabular}

Where

$\mathrm{R}_{\mathrm{ij}}=$ Rank given for the $\mathrm{i}^{\text {th }}$ variable by $\mathrm{j}^{\text {th }}$ respondents

$\mathrm{N}_{\mathrm{j}}=$ Number of variable ranked by $\mathrm{j}^{\text {th }}$ respondents

The percent position of each rank was converted to scores by referring to tables given by Garret and Woodworth (1969). Then for each factor, the scores of individual respondents were summed up and divided by the total number of respondents for whom scores were gathered. The mean scores for all the factors were ranked, following the decision criterion that higher the value the more important it will be in order of preference given by customers.

\section{Garret's ranking table}

\begin{tabular}{|c|c|c|c|}
\hline Sl no & Variables & Score & Rank \\
\hline 1 & Unemployment & 5232 & I \\
\hline 2 & Drought & 2763 & IV \\
\hline 3 & Low productivity & 1727 & V \\
\hline 4 & Loan & 3414 & III \\
\hline 5 & Drinking water problem & 438 & VI \\
\hline 6 & Low wage & 4081 & II \\
\hline
\end{tabular}

The above table represents the reasons for migration and ranking has been made. Though there are many factors which are influencing the labourers to migrate. According to Garret's ranking technique table unemployment/ Seasonal employment is one of the important reasons to migrate; second foremost reason is low wage. Compared to agriculture, construction wages are high hence they are migrate to higher waged construction area. Accessibility to loans is also pulling them to migrate to higher waged construction area which was ranked third in Garret ranking table. Another reason was drought and low productivity in agriculture. North Karnataka has been the victim of regular droughts leading to loss of agricultural productivity and lack of water even for drinking purpose. This has been highlighted by some of the migrants as one of the causes of migration as lack of potable water will lead to many infections and diseases particularly to children.

Since unemployment is the foremost reason for migration, as per the Garett's ranking technique null hypothesis is rejected and alternate hypothesis is accepted in this work.

\section{Conclusion:}

The above study helps us to make some observation as below.

The migrant labourers from North Karnataka are becoming the main labour source to the construction sector in the cities and the construction works of the cities are pulling these labourers because of high wages. Migrated labourers are coming to southern region in good number for employment to fulfill their financial as well as social needs. Many of the social economic, political reasons are playing important role to pull them into migration by solving the financial and livelihood problem and improving their standard of living. Above ranking technique shows that out of all it is unemployment faced by the agricultural labourers in this region which is significantly influencing their migration to south Karnataka.

\section{Reference:}

[1]. Amitabh Kundu and Shalini Gupta (1996)Migration, Urbanisation and Regional Inequality", Economic and Political Weekly, Vol. 31, No. 52 , pp. 3391-3393+3395-3398.

[2]. Amitabh Kundu(2009)" Exclusionary Urbanization in Asia: A Macro Overview” Economic and Political Weekly, Vol. 44, No. 48, pp.48-58,

[3]. Amitabh Kundu(2011) “Trends And Processes Of Urbanisation In India”, Urbanization And Emerging Population Issues- 6 ,Human Settlement Group, IIED. Population And Development Branch, UNFPA. 
[4]. Biplab Dasgupta (1987)" Urbanization and Rural Change in West Bengal”, Economic and Political Weekly, Vol. 22, No. 7 , pp. 276287.

[5]. Bryan R. Roberts (1989) "Urbanization, Migration, and Development” Sociological Forum, Vol. 4, No. 4, Special Issue: Comparative National Development: Theory and Facts for the 1990s , pp. 665-691.

[6]. Deshinkar, priya (2006) international migration .poverty and development in Asia, downloaded from website www.asia 2015conferenceorg/pdhs/deshingkar.pdf.

[7]. Global Economic Prospects (2006) the World Bank.

[8]. Improving Statistics on International Migration in Asia Author(s): Graeme Hugo Reviewed work(s):Source: International Statistical Review / Revue Internationale de Statistique, Vol. 74, No. 3

[9]. J,Edward Taylor, Joaquin Arango,(1996), International Migration and Community Development, Population Index, Vol. 62, No. 3, pp. 397-418.

[10]. Jajati Keshari Parida,S Madheswaran,(2011) "Determinants Of Migration And Remittance In India, Empirical Evidence" The Institute for Social and Economic Change, Bangalore, Working paper272.

[11]. M.H. Wani, Shahid Yousuf, S.H. Baba and S.A. Wani(2011), "agricultural labour migration: causes and implications", Agricultural Economics Research Review Vol. 24 (Conference Number) 2011

[12]. Mac Kinnon, R.1975. Controlling inter-regional migration processes of a Markovian type. Environment and Planning A 7:781-92.

[13]. Omprakash Parganiha1, M.L. Sharma2, P.M. Paraye,(2009)Migration Effect of Agricultural Labourers on Agricultural Activities, Indian Res. J. Ext. Edu. 9 (3), September, 2009

[14]. Per Lundborg and Paul S. Segerstrom (2000), International Migration and Growth in Developed Countries: A Theoretical Analysis, Economica, New Series, Vol. 67, No. 268 (Nov., 2000), pp. 579-604. 